\title{
$\nabla$
}

\section{Prevalence of dermatological complaints in patients undergoing treatment for breast cancer ${ }^{*}$}

\author{
Tamara Hoffmann ${ }^{1}$ \\ Camila Soares Duarte ${ }^{1}$ \\ Ana Beatriz Sanches Barranco ${ }^{1}$
}

\author{
Mariane Corrêa-Fissmer ${ }^{2}$ \\ Rayane Felippe Nazário ${ }^{1}$ \\ Karen Waleska Knipoff de Oliveira ${ }^{1}$
}

DOI: http:/ / dx.doi.org/10.1590/abd1806-4841.20186541

Abstract: BACKGROUND: Internal malignancies such as breast cancer, as well as their treatment can often result in skin changes. Овјестіvе: To assess the prevalence of dermatological complaints in patients who are undergoing oncological treatment for breast cancer in a hospital in Tubarão, Santa Catarina, Brazil.

Methods: Observational, cross-sectional study, from October 2015 to February 2016 in which 152 patients with the diagnosis of breast cancer, undergoing treatment with chemotherapy, radiotherapy, hormone therapy and/or surgery, were interviewed and completed a research protocol developed by the author.

RESULTS: The treatment of breast cancer was associated with dermatological complaints in $94.1 \%$ of the interviewed, being with hair loss the most frequent, present in $79.6 \%$ of the sample, followed by nail changes (56\%). Patients with lighter skin phototypes (I, II and III) had a lower risk $(p=0.045)$ of developing skin changes when compared to darker phototypes. Radiation therapy $(p=0.011)$ and oncological surgery $(p$ Fisher $=0.004)$ were statistically significant when related to skin changes.

StUdy LIMITATIONS: Inherent to the design of the study, as well as recall bias.

CONCLUSIONS: It was found that most patients diagnosed with breast cancer showed dermatologic manifestations during the proposed cancer treatment. Patients undergoing radiotherapy and surgery showed skin changes with greater statistical significance. Keywords: Breast neoplasms; Drug therapy; Radiotherapy; Skin

\section{INTRODUCTION}

Breast cancer is the second most frequent type of cancer in the world and the most common among women, either in developing or developed countries and in Brazil it has an estimated gross rate of 57,960 new cases for 2016. ${ }^{1}$ It affects more frequently women around 50 years of age. However, in the last decades, it was observed an increase of the global incidence of this malignancy, including in younger age groups, as well as a mortality rate that is also growing in the country, what can be explained by the fact that the disease is still diagnosed in advance stages. ${ }^{2}$ Thus, the importance of researches on the primary prevention of this malignancy and its interventions is clear. ${ }^{1}$

As treatment modalities for this malignancy, there is surgery and radiotherapy for locoregional treatment, besides chemotherapy and hormone therapy for systemic treatment. ${ }^{3}$
Internal malignancies such as breast cancer can frequently cause cutaneous manifestations due to direct effects, i.e., invasion of the skin by a tumor or its metastasis, or by indirect effects that trigger cutaneous signs and/or symptoms. ${ }^{4}$ It is also known that cancer treatment itself with chemotherapy and radiotherapy, for example, are also related to the appearance of multiple side effects on the on the skin of cancer patient. ${ }^{5,6}$ Besides the skin itself, hair and nails, complex adnexal structures, indirectly influenced by the physiological state of the patient, can also be affected by internal malignancies, as well as by their treatment. ${ }^{5}$

For example, chemotherapy drugs like doxorubicin, cyclophosphamide, fluouracil and docetaxel, act on cells that have a high rate of multiplication, acting not only on neoplastic cells, but also on any cell in the organism with a high metabolism, therefore affect-

\footnotetext{
Received 05 October 2016.

Accepted 16 March 2017.

* Work conducted at Hospital Nossa Senhora da Conceição (HNSC), Tubarão (SC), Brazil.

Financial support: None.

Conflict of interest: None.

Medical Specialties Outpatient Clinic, Department of Medicine, Universidade do Sul de Santa Catarina (Unisul), Tubarão (SC), Brazil. Department of Sensory System, Medicine Course, Universidade do Sul de Santa Catarina (Unisul), Tubarão (SC), Brazil.
} 
ing the skin and its appendages. ${ }^{7}$ Despite the lack of exact numbers, since there are no epidemiological studies of these drugs used separately, an incidence of $65 \%$ is estimated related to their use. ${ }^{8}$ Among the most frequent are alopecia, hypersensitivity reactions and nail changes. ${ }^{9}$

Radiotherapy can also cause numerous effects on cutaneous tissue, from a mild erythema on the breast in mild cases to cutaneous necrosis with an increased risk for ulcers and malignant transformation in severe cases. ${ }^{10,11}$ Surgical excision of the tumor can also result in local sequelae, either cosmetic or functional, such as atrophic, hypertrophic and keloid scarring, hyperpigmentation, fibrosis and others. ${ }^{12}$ Hormonal therapy, more frequently with tamoxifen, is associated to an incidence of $19 \%$ of cutaneous reactions at any given point during the treatment course, from common adverse events of "heat waves" to rare outcomes such as Stevens-Johnson syndrome. ${ }^{13}$

Due to the high incidence rates of breast cancer patients and knowing that the diverse dermatological changes, either from the disease itself or its treatment, can lead to substantial consequences in the quality of life of patients, this study had the objective of evaluate the prevalence of dermatological conditions in patients undergoing oncological treatment for breast cancer at the Hospital Nossa Senhora da Conceição in Tubarão, Santa Catarina.

\section{METHODS}

It is an observational, cross-sectional study performed from October 2015 to February 2016. One hundred and fifty-two patients with the diagnosis of breast cancer who were undergoing treatment with chemotherapy, radiotherapy, hormone therapy and/or in preor post-surgical consultations at the Hospital Nossa Senhora da Conceição were interviewed.

All patients older than 18 years of age who were undergoing treatment for breast cancer at the Hospital Nossa Senhora da Conceição, during the period of the study were included, and the patients who did not agree to participate in the study and those with incomplete medical records were excluded. Data were collected during an interview, through a questionnaire designed by the author, during the waiting period for the patient's consultation or treatment. The collection was performed by five medical students of the course of Medicine at Universidade do Sul de Santa Catarina, being the author and other four collaborators properly trained for her standardization. Information regarding breast cancer histological subtype was accessed by analyzing the electronic medical records of the service, via the Philips Tasy system, used by the Hospital Nossa Senhora da Conceição, for completion of the research protocol created by the author.

Any cutaneous complaints occurring during the treatment of the patients with breast cancer were taken into consideration, and the complaints previous to the treatment were excluded. This information was considered when described in the medical record and/ or reported by the patient during follow-up. Variables of interest were sex, age at diagnosis, marital status, occupation, schooling, origin, family history of breast cancer, phototype, histological type of breast cancer, treatments and intercurrent dermatological complaints.
Data were organized in the software Microsoft Excel and analyzed in the software SPSS 15.0. Qualitative variables such as sex, marital status, occupation, schooling, family history, phototype, histological type of the cancer, previous and current treatments, as well as dermatological complaints were described as absolute and relative frequencies; on the other hand, quantitative variables such as age at diagnosis, as measurements of central tendency and data dispersion. Comparison of rates were evaluated by the chi-square test and comparison of mean by Student T-test or nonparametric correspondents. The level of significance established was of $5 \%$ and the confidence interval of $95 \%$.

This research was submitted to the Committee of Ethics in Research with Humans and was approved under the protocol number 1.541.235.

\section{RESULTS}

The study sample was comprised of 152 patients. All members were female, with a mean age of 53.32 years (standard deviation $=12.956)$ and had the diagnosis of breast cancer followed at Hospital Nossa Senhora da Conceição. All patients had been submitted to treatments as chemotherapy, radiotherapy, hormone therapy and/or surgery. Table 1 shows all the sociodemographic data of the population interviewed.

Regarding the histologic type of the tumor, the most frequent was the invasive ductal carcinoma in 134 patients, what corresponds to $88.2 \%$ of the cases, followed by the invasive lobular carcinoma, as shown in table 2.

All participants had already gone through or were undergoing a treatment regimen for breast cancer when interviewed for this study. The most frequent treatment among patients of the sample was chemotherapy, with 129 (84.9\%) patients. The second most common treatment was surgery, in 127 (83.5\%) women, followed by hormone therapy in $93(61.2 \%)$, and lastly radiotherapy in 86 $(56.6 \%)$ patients.

During the treatment for breast cancer, 143 (94.1\%) participants had some kind of dermatological complaint, being hair loss the most frequent change seen in 121 (79.6\%) patients. Table 3 shows the frequency of dermatological complaints according to each treatment.

Besides that, $34(22.4 \%)$ patients reported the presence of a local dermatological change at the moment of diagnosis of the malignancy. Fifteen $(9.9 \%)$ patients referred mammary retraction, $14(9.2 \%)$, nipple inversion, 4 (2.6\%), breast with an "orange peel" aspect and $3(2.0 \%)$, extension of the neoplasia underlying skin.

From the data analysis we observed that the patients that underwent radiotherapy had more frequent dermatological complaints, which was statistically significant (PR:1.13; CI95\%:1.03 to $1.23 ; p=0.011)$. In the same way, surgery was a factor also associated to dermatological changes. Patients who underwent surgery had a 20\% chance of dermatological changes (PR:1.24; CI95\%:1.02 to 1.54; $p_{\text {Fisher }}=0.004$ ).

Chemotherapy $(p=0.138)$, hormone therapy $(p=0.311)$ and histological type of the tumor $(p=0.288)$ were not statistically significantly frequently associated to dermatological manifestations.

The most frequent skin phototype according to Fitzpatrick 
TABLE 1: Distribution of the patients according to sociodemographic variables obtained at the time of diagnosis of breast cancer. Tubarão, $2015(\mathrm{n}=152)$

\begin{tabular}{|c|c|c|}
\hline Characteristics & $\mathbf{N}$ & $\%$ \\
\hline \multicolumn{3}{|l|}{ Age group } \\
\hline Younger than 30 & 4 & 2.6 \\
\hline $30-39$ & 19 & 12.5 \\
\hline $40-49$ & 39 & 25.6 \\
\hline $50-59$ & 37 & 24.3 \\
\hline $60-69$ & 35 & 23.0 \\
\hline 70 or older & 18 & 11.8 \\
\hline \multicolumn{3}{|l|}{ Marital status } \\
\hline Single & 21 & 13.8 \\
\hline Married & 88 & 57.9 \\
\hline Divorced & 12 & 7.9 \\
\hline Widow & 31 & 20.4 \\
\hline \multicolumn{3}{|l|}{ Origin } \\
\hline Tubarão & 54 & 35.5 \\
\hline Laguna & 18 & 11.8 \\
\hline Braço do Norte & 13 & 8.6 \\
\hline Capivari de Baixo & 11 & 7.2 \\
\hline Imbituba & 10 & 6.6 \\
\hline Other & 46 & 30.3 \\
\hline \multicolumn{3}{|l|}{ Occupation } \\
\hline Retiree/pensioner & 72 & 47.4 \\
\hline House wife & 23 & 15.2 \\
\hline Unemployed & 3 & 2.0 \\
\hline Other & 54 & 35.4 \\
\hline \multicolumn{3}{|l|}{ Schooling } \\
\hline Illiterate & 1 & 0.7 \\
\hline Incomplete middle school & 79 & 52.0 \\
\hline Complete middle school & 18 & 11.2 \\
\hline Incomplete high school & 6 & 3.9 \\
\hline Complete high school & 37 & 24.3 \\
\hline University degree & 6 & 3.9 \\
\hline Post-graduation & 5 & 3.3 \\
\hline \multicolumn{3}{|c|}{ Family history of breast cancer } \\
\hline Positive & 29 & 19.1 \\
\hline Negative & 123 & 80.9 \\
\hline \multicolumn{3}{|l|}{ Phototype } \\
\hline I & 17 & 11.2 \\
\hline II & 41 & 27.0 \\
\hline III & 29 & 19.1 \\
\hline IV & 28 & 18.4 \\
\hline V & 29 & 19.1 \\
\hline VI & 8 & 5.3 \\
\hline
\end{tabular}

TABLE 2: Distribution of patients according to the histological type of breast cancer. Tubarão, $2015(\mathrm{n}=152)$

\begin{tabular}{lcc} 
Histological type & $\mathbf{N}$ & $\%$ \\
\hline Invasive Ductal & 134 & 88.2 \\
Invasive Lobular & 5 & 3.3 \\
Intraductal & 2 & 1.3 \\
Lobular in situ & 1 & 0.7 \\
Tubular & 1 & 0.7 \\
Mucinous & 1 & 0.7 \\
Papillary & 1 & 0.7 \\
Metaplastic & 1 & 0.7 \\
Outros & 6 & 3.7 \\
\hline
\end{tabular}

was II in $41(27 \%)$ patients. However, according to the association of phototypes and the incidence of dermatological changes, patients with lighter phototypes (I, II and III) had a lower chance of dermatological changes $(8 \%)$ when compared to darker phototypes (IV, $\mathrm{V}$ and VI) (PR:0.92; CI95\%:0.86 to 0.99; $p_{\text {Fisher }}=0.045$ ). In a similar way, patients with skin phototype VI had a three-fold higher prevalence of dystrophic scarring compared to phototypes I to V (PR:3,00; CI $95 \%: 1.11$ to $8.10 ; p=0.046)$.

\section{DISCUSSION}

Data of general characterization show that, of the patients studied, around $50 \%$ belonged the age group of 40 to 59 years, finding also found in a study performed in Florianópolis (SC) - Brazil, that demonstrated that the majority $(56.3 \%)$ of the patients diagnosed with breast cancer were in the same age group. ${ }^{14}$ Regarding marital status, most patients of the study $(57.9 \%)$ were married, consistent with other studies. ${ }^{14,15}$

Most of the interviewed (52.0\%) had incomplete middle school, what determines a risk 3.76-fold higher of death by breast cancer, what could be explained by the fact that a higher schooling is related to higher chances of the patient to undergo clinical and radiographical examination of the breasts, allowing for earlier diagnosis and treatment. ${ }^{14,16}$

Despite family history in first degree relatives being considered a well-established risk factor for breast cancer, increasing the relative risk two-fold, of the study group, only $19.1 \%$ had a positive family history. ${ }^{17}$ In addition, this seems to be the risk factor with the greatest impact regarding the encouragement for preventive practices as performing mammograms and routine gynecological examinations. ${ }^{18,19}$

The prevalence of invasive ductal carcinoma was the highest, corresponding to $88.2 \%$ of the patients, with a profile similar to other studies. ${ }^{14,20-23}$

Hochman B et al ${ }^{24}$ note in their research that the darker the skin phototype according to Fitzpatrick, the higher the tendency to develop fibroproliferative scars, classified in keloid, hypertrophic and mixed scars. The objective of this study was not to specify the type of scar reported by the patients but we observed a significant association ( $p=0.046$ ) between skin phototype VI and the development of scars, thus supporting data already present in the literature. 
TABLE 3: Distribution of the sample according to dermatological complaints during breast cancer treatment. Tubarão, 2015 $(\mathrm{n}=152)$

\begin{tabular}{|c|c|c|c|c|}
\hline \multirow{2}{*}{$\begin{array}{l}\text { Dermatological } \\
\text { complaint }\end{array}$} & CT & RT & HT & Surgery \\
\hline & $\begin{array}{c}n=129 \\
(\%)\end{array}$ & $\begin{array}{c}n=86 \\
(\%)\end{array}$ & $\begin{array}{c}n=93 \\
(\%)\end{array}$ & $\begin{array}{c}n=127 \\
(\%)\end{array}$ \\
\hline Nail changes & $\begin{array}{c}67 \\
(44.0)\end{array}$ & $5(3.2)$ & $12(7.9)$ & $1(0.7)$ \\
\hline Hair loss & $\begin{array}{c}117 \\
(76.9)\end{array}$ & $4(2.6)$ & 0 & 0 \\
\hline Dystrophic scar & 0 & $3(2.0)$ & 0 & $18(11.8)$ \\
\hline Breast erythema & $4(2.6)$ & $63(41.4)$ & $14(9.2)$ & $11(7.2)$ \\
\hline $\begin{array}{l}\text { Breast hyperpig- } \\
\text { mentation }\end{array}$ & $7(4.6)$ & $55(36.1)$ & $10(6.5)$ & $8(5.2)$ \\
\hline Breast rubor & $5(3.2)$ & 45 (29.6) & $10(6.5)$ & $3(2.0)$ \\
\hline $\begin{array}{l}\text { Palmoplantar } \\
\text { hyperkeratosis }\end{array}$ & $\begin{array}{c}37 \\
(24.3)\end{array}$ & $9(5.9)$ & $12(7.9)$ & $2(1.3)$ \\
\hline $\begin{array}{l}\text { Wounds/ulcers } \\
\text { on the breast }\end{array}$ & 0 & $20(13.1)$ & $4(2.6)$ & 0 \\
\hline $\begin{array}{l}\text { Blisters in the } \\
\text { breast }\end{array}$ & $1(0.7)$ & $20(13.1)$ & $2(1.3)$ & $1(0.7)$ \\
\hline $\begin{array}{l}\text { Dryness of the } \\
\text { breast }\end{array}$ & $\begin{array}{c}16 \\
(10.5)\end{array}$ & $27(17.7)$ & $12(7.9)$ & $2(1.3)$ \\
\hline Breast pruritus & $11(7.2)$ & $18(11.8)$ & $15(9.8)$ & $18(11.8)$ \\
\hline Diffuse pruritus & $8(5.2)$ & $3(2.0)$ & $8(5.2)$ & $1(0.7)$ \\
\hline Hirsutism & $10(6.5)$ & $4(2.6)$ & $4(2.6)$ & $1(0.7)$ \\
\hline Hypertrichosis & $10(6.5)$ & $12(7.9)$ & $10(6.5)$ & $1(0.7)$ \\
\hline $\begin{array}{l}\text { Hyperhidrosis/ } \\
\text { hot flushes }\end{array}$ & $\begin{array}{c}22 \\
(14.4)\end{array}$ & $6(3.9)$ & $\begin{array}{c}48 \\
(31.6)\end{array}$ & $2(1.3)$ \\
\hline Anhidrosis & $2(1.3)$ & 0 & 0 & $2(1.3)$ \\
\hline Oral ulcers & $12(7.9)$ & $2(1.3)$ & $3(2.0)$ & $2(1.3)$ \\
\hline
\end{tabular}

CT: chemotherapy.

RT: radiotherapy.

HT: hormone therapy.

$\%$ : corresponds to the percentage of each change in the total sample.

Andrew $\mathrm{P}$ et $a l^{13}$, in their systematic review on cutaneous reaction related to the use of tamoxifen in breast cancer, reported that nearly $20 \%$ of the patients had cutaneous changes at any point during treatment, ranging from more common manifestations as rubor to other potentially fatal as Stevens-Johnson syndrome. In the same way, we observed in the present study a frequency of $69 \%$ of dermatological changes that occurred during hormone therapy. Moreover, the use of hormone therapy was associated to the appearance of hot flushes in $51,6 \%$ of the patients, consistent with the study by Leite $e t a l .{ }^{25}$, found it to be the main side effect of the use of tamoxifen in patients being treated for breast cancer.

Cutaneous side effects due to radiotherapy are common and sometimes severe, even leading to reduce the treatment duration. ${ }^{26,27}$ These effects can be acute or chronic. Acute effects are those that occur hours to weeks after exposure to radiation and are characterized by erythema, edema, scaling, hyperpigmentation and local alopecia. Chronic effects tend to be more severe and occur months to years after the exposure and can present as ulcers, necrosis and fibrosis. ${ }^{28} \mathrm{Hu}$ et al. ${ }^{29}$ observed that $95.1 \%$ of the women with cancer receiving radiotherapy as adjuvant treatment had acute cutaneous reactions to the radiation. In the same way, this study obtained a similar frequency, in which $97.6 \%$ of the patients exposed to radiation had dermatological changes. The most reported complaint was erythema of the breast, followed by hyperpigmentation, present in $73.2 \%$ and $64 \%$ of the patients treated with radiation, respectively, what is in contrast with another study that assessed the effects of post-operatory radiotherapy, in which hyperpigmentation and fibrosis were detected in $52 \%$ of the patients. ${ }^{30}$ The study by Hu et $a l .{ }^{29}$ also demonstrated hyperpigmentation on the breast of women treated with radiotherapy, as well as xerosis, complaints reported in $20.9 \%$ of the irradiated patients in this study. This is due to the fact that the skin, an organ that is continually renewed, is highly susceptible to radiation injury, leading to acute and late cutaneous changes, and therefore, radiotherapy is associated to a higher prevalence of those $(p=0.011) \cdot{ }^{31}$ Moreover, Patani $e t a l^{32}$, suggest in a study that patients submitted to surgery and adjuvant radiotherapy had a worse cosmetic outcome when compared to the patients that did not undergo radiotherapy.

On the other hand, chemotherapy is also related to multiple dermatological changes such as alopecia, erythema, itch, xerosis, acne, hypersensitivity reactions, local desquamation and nail changes and, because its target are proliferating cells, the dermatological reactions are the most common side effects in cancer patients treated with chemotherapy. ${ }^{33}$ This study found that the complaint of hair loss was the most frequent event related to chemotherapy, reported by 117 patients. This is considered the first dermatological manifestation from the use of antineoplastic drugs, appearing straight after the beginning of the treatment and occurs due to the trichorrhexis, fragmentation, reduction in the diameter and depigmentation of the hair. ${ }^{33}$ Nail changes are also considered frequent. Heidary $e a^{34}$, observed them in their update in around 10 to $15 \%$ of the patients treated with chemotherapy, typically as late events, that usually appear between 4 to 8 weeks of treatment. Calderón et $a l^{35}$, in a comparative study performed in Mexico, evaluated the frequency of nail changes secondary to chemotherapy with taxanes and observed that $56 \%$ of the patients developed such changes, the more common being melanonychia, Beau's lines, Muehrcke's lines and longitudinal streaks. Other nail changes induced by chemotherapy are subungual hematoma and onycholysis, with the clinical presentation influenced by the duration of treatment and the degree of toxicity of each antineoplastic drug. ${ }^{36}$ Winther et $a l^{37}$ evaluated nail changes in patients with metastatic breast cancer during treatment with docetaxel, and their study shows that $55 \%$ of the patients had some degree of nail changes. In this study, the data were also in agreement with the literature, and we observed that approximately $52 \%$ of the patients treated with chemotherapy reported some nail change. Other changes related to chemotherapy were seen in the study by Kang et $a l^{38}$, in which the complaint of dry skin in patients being treated for breast cancer was reported by $57.9 \%$ of the patients, a higher frequency than that found in this research, which was $12.6 \%$.

Regarding oncological surgery of the breasts, the presence 
of dystrophic scars was reported as the main associated change, seen in nearly $14 \%$ of patients. Febra et $a l^{12}$ presented in their study lymphedema as the main cosmetic dermatologic change caused by oncological surgery, present in $32 \%$ of the patients evaluated and only $4 \%$ reported hyperpigmentation on the site of the surgery. This data is in contrast to the present study, in which hyperpigmentation was present in $6.2 \%$ of the mastectomized patients. Therefore, surgery was associated to a higher prevalence of dermatological complaints $(p=0.004)$, as well as radiotherapy.

Crippa $e a^{39}$, in their study about breast cancer in younger patients, demonstrated that $75.4 \%$ of women seek medical attention due to a breast nodule and $22.4 \%$ because they have symptoms, whereasin the current study $22.4 \%$ of the patients reported cutaneous lesions on the breast at the time of diagnosis of cancer, what demonstrates the difficulty in self-diagnosing breast cancer early, leading to late diagnoses, advanced stages and worse prognosis.

\section{CONCLUSION}

This research contributes for the identification of the profile of patients with the diagnosis of breast cancer, which as female, are mostly in the age group of 40-69 years, are married, retired or pensioners and have incomplete middle school. Besides, the evaluation of the prevalence of dermatological complaints in these patients reveals that most had some kind of dermatological change during the treatment, statistically significant for the patients submitted to radiotherapy and surgery. These findings allow the elaboration of intervention strategies in order to minimize potential side effects from the treatment, be it chemotherapy, hormone therapy, radiotherapy and/or surgical. It is worth highlighting that a large number of interviewees reported dermatological changes at the time of diagnosis of cancer, showing that, in these cases, the diagnosis was not made early.

Therefore, we alert for the importance in continuing studies regarding this subject, in order to improve the quality of life regarding to the dermatological aspects of the patients being treated for breast cancer.

As limitations of this study, we can cite those inherent to the study design, as well as recall bias. $\square$

\section{REFERENCES}

1. Inca.gov.br [Internet]. Instituto Nacional do Câncer. Estimativa 2016. Incidência de Câncer no Brasil. Rio de Janeiro: INCA, 2015. [acesso 12 Abr 2016]. Disponível em: http://www.inca.gov.br/estimativa/2016/estimativa-2016-v11.pdf.

2. Santos Junior JC, Soares LFM. Câncer de Mama. In: Vieira SC, Lustosa AML, Barbosa CNB, Teixeira JMR, De Brito LXE, Soares LFM, et al. Oncologia Básica. 1ed. Teresina: Fundação Quixote; 2012. p.41-60.

3. Barbosa EM, Francisco AARF, Araujo Neto JT, Alves EMF, Tavares MGM, Góes JCS. Fatores clínico-patológicos de predição do acometimento axilar em pacientes com metástases de câncer de mama no linfonodo sentinela. Rev. Bras. Ginecol. Obstet. 2010;32:144-9.

4. Yuste-Chaves M, Unamuno-Pérez P. Cutaneous Alerts in Systemic Malignancy: Part I. Actas Dermosifiliogr. 2013;104:285-98.

5. Hinds G, Thomas VD. Malignancy and cancer treatment-related hair and nail changes. Dermatol Clin. 2008;26:59-68, viii.

6. Piérard-Frachimont C, Piérard GE. Comment j'explore. une perte de cheveux chez un patient cancéreux. Rev Med Liege. 2004;59:525-9.

7. Payne AS, James WD, Weiss RB. Dermatologic toxicity of chemotherapeutic agents. Semin Oncol. 2006;33:86-97.

8. Donati A, Castro LGM. Cutaneous adverse reactions to chemotherapy with taxanes. The dermatologist's point of view. An Bras Dermatol. 2011;86:755-8.

9. Cortes JE, Pazdur R. Docetaxel. J Clin Oncol. 1995;13:2643-55

10. Rupprecht R, Lippold A, Auras C, Bramkamp G, Breitkopf C, Elsmann HJ, et al. Late side-effects with cosmetic relevance following soft X-ray therapy of cutaneous neoplasias. J Eur Acad Dermatol Venereol. 2007;21:178-85.

11. Pezzano $M$, Duterque $M$, Lardoux $H$, Louvard $Y$, Morice MC, Lefèvre $T$, et al. Radiodermite thoracique en cardiologie interventionnelle. A propos de 6 cas. Arch Mal Couer Vaiss. 1999;92:1197-204.

12. Fabra DG, Kayo AP, Leal ARO, Salzano V, Guglielmino F. Alterações dermatológicas em pacientes oncológicos - adultos e crianças. Arq Bras Ciênc Saúde. 2009:34:87-93

13. Andrew P, Valiani S, Maclsaac J, Mithoowani H, Verma S. Tamoxifen-associated skin reactions in breast cancer patients: from case report to literature review. Breast Cancer Res Treat. 2014;148:1-5

14. Schneider IJC, d'Orsi E. Sobrevida em cinco anos e fatores prognósticos em mulheres com câncer de mama em Santa Catarina, Brasil. Cad. Saúde Pública. 2009;25:1285-96.

15. Brito NMB, Kabacznik A, Costa NA, Bardier AMO, Silva DS, Coqueiro RB. Perfil epidemiológico das pacientes com neoplasia maligna de mama atendidas no Hospital Ofir Loyola. Rev. Para Med. 2001:18:49-54.
16. Molina L, Dalben I, De Luca LA. Análise das oportunidades de diagnóstico precoce para as neoplasias malignas de mama. Rev. Assoc. Méd. Bras. 2003;49:185-90.

17. Tessaro S. Epidemiologia do câncer de mama. In: Basegio DL. Câncer de mama: abordagem multidisciplinar. Rio de Janeiro: Revinter; 1999. p.1:1-10.

18. Sclowitz ML, Menezes AMP, Gigante DP, Tessaro S. Condutas na prevenção secundária do câncer de mama e fatores associados. Rev. Saúde Pública. 2005;39:340-9.

19. Pharoah PD, Day NE, Duffy S, Easton DF, Ponder BA. Family history and the risk of breast cancer: a systematic review and meta-analysis. Int J Cancer. 1997;71:800-9.

20. Moraes AB, Zanini RR, Turchiello MS, Riboldi J, De Medeiros LR. Estudo da sobrevida de pacientes com câncer de mama atendidas no hospital da Universidade Federal de Santa Maria, Rio Grande do Sul, Brasil. Cad. Saúde Pública. 2006;22:2219-28.

21. Vazquez T, Krygier G, Barrios E, Cataldi S, Vazquez A, Alonso R, et al. Análisis de sobrevida de una población con cáncer de mama y su relación con factores pronósticos: estudio de 1.311 pacientes seguidas durante 230 meses. Rev. Med. Urug. 2005:21:107-21.

22. De Abreu E, Koifman S. Fatores prognósticos no câncer de mama feminino. Rev. Bras. Cancerol. 2002:48:113-31.

23. Brito C, Portela MC, Vasconcellos MTL. Sobrevida de mulheres tratadas por câncer de mama no Estado do Rio de Janeiro. Rev. Saúde Pública. 2009:43:481-9.

24. Hochman B, Farkas CB, Isoldi FC, Ferrara SF, Furtado F, Ferreira LM. Distribuição de queloide e cicatriz hipertrófica segundo fotótipos de pele de Fitzpatrick. Rev. Bras. Cir. Plást. 2012;27:185-9.

25. Leite FMC, Bubach S, Amorim MHC, De Castro DS, Primo CC. Mulheres com Diagnóstico de Câncer de Mama em Tratamento com Tamoxifeno: Perfil Sociodemográfico e Clínico. Rev. Bras. Cancerol. 2011;57:15-21.

26. Hymes SR, Strom EA, Fife C. Radiation dermatitis: clinical presentation, pathophysiology, and treatment 2006. J Am Acad Dermatol. 2006;54:28-46.

27. Harper JL, Franklin LE, Jenrette JM, Aguero EG. Skin toxicity during breast irradiation: pathophysiology and management. South Med J. 2004;97:989-93.

28. Ryan JL. Ionizing radiation: the good, the bad, and the ugly. J Invest Dermatol. 2012;132:985-93

29. Hu SC, Hou MF, Luo KH, Chuang HY, Wei SY, Chen GS, et al. Changes in biophysical properties of the skin following radiotherapy for breast cancer. J Dermatol. 2014:41:1087-94.

30. Pessoa SGP, Matos JRF, Dias IS, Peixoto DTT, Araújo JS. Impacto da radioterapia adjuvante no resultado cosmético da reconstrução mamária imediata com retalho TRAM. Rev. Bras. Cir. Plást. 2012;27:411-4. 
31. Salvo N, Barnes E, van Draanen J, Stacey E, Mitera G, Breen D, et al. Prophylaxis and management of acute radiation-induced skin reactions: a systematic review of the literature. Curr Oncol. 2010;17:94-112.

32. Patani N, Mokbel K. Oncological and aesthetic considerations of skin-sparing mastectomy. Breast Cancer Res Treat. 2008;111:391-403.

33. Pai GS, Vimala AM, Dinesh M. Occurrence and severity of alopecia in patients on combination chemotherapy. Indian J Cancer. 2000;37:95-104.

34. Heidary N, Naik H, Burgin S. Chemotherapeutic agents and the skin: An update. J Am Acad Dermatol. 2008;58:545-70.

35. Calderón L, Tirado-Sánchez A, Lázaro-León JM, Ponce-Olivera RM, Bonifaz A. Frecuencia de alteraciones ungueales secundarias a la administración de taxanos en pacientes mexicanos. Dermatol Rev Mex. 2015;59:493-503.
36. Minisini AM, Tosti A, Sobrero AF, Mansutti M, Piraccini BM, Sacco C, et al Taxane-induced nail changes: incidence, clinical presentation and outcome. Ann Oncol. 2003;14:333-7.

37. Winther D, Saunte DM, Knap M, Haahr V, Jensen AB. Nail changes due to docetaxel--a neglected side effect and nuisance for the patient. Support Care Cancer. 2007;15:1191-7.

38. Kang D, Kim IR, Im YH, Park YH, Ahn JS, Lee JE, et al. Quantitative changes in skin composition parameters due to chemotherapy in breast cancer patients: a cohort study. Breast Cancer Res Treat. 2015;152:675-82.

39. Crippa CG, Hallal ALC, Dellagiustina AR, Traebert EE, Gondin G, Pereira C. Perfi Clínico e Epidemiológico do Câncer de Mama em Mulheres Jovens. Arq. Catarin. Med. 2003;32:50-8

$\begin{array}{ll}\text { Tamara Hoffmann } & \text { (iD) ORCID 0000-0002-5218-8506 } \\ \text { Mariane Corrêa-Fissmer } & \text { (iD) ORCID 0000-0003-2382-7150 } \\ \text { Camila Soares Duarte } & \text { iD ORCID 0000-0002-5755-6742 }\end{array}$

$\begin{array}{ll}\text { Rayane Felippe Nazário } & \text { (iD) ORCID 0000-0003-2323-0215 } \\ \text { Ana Beatriz Sanches Barranco } & \text { iD ORCID 0000-0001-9481-2488 } \\ \text { Karen Waleska Knipoff de Oliveira } & \text { iD ORCID 0000-0001-6804-0058 }\end{array}$

How to cite this article: Hoffmann T, Fissmer MC, Duarte CS, Nazário RF, Barranco ABS, de Oliveira KWK. Prevalence of dermatological complaints in patients undergoing treatment for breast cancer. An Bras Dermatol. 2018;93(3):362-7. 